Ritstýrð grein birt 31. desember 2018

\title{
Starfshættir í framhaldsskólum: Aðdragandi og framkvæmd rannsóknar 2012-2018
}

\author{
Gerður G. Óskardóttir og rannsóknarhópur um starfshætti í framhaldsskólum
}

- Abstract Um höfundinn $\quad$ About the author Heimildir

Rannsóknin Starfshættir í framhaldsskólum fór fram á árunum 2012-2018. Hún var samstarfsverkefni rúmlega 20 manna hóps rannsakenda, bæði kennara og nemenda við Menntavísinda- og Félagsvísindasvið Háskóla Íslands með aðsetur á Rannsóknastofu um próun skólastarfs á Menntavísindasviði. Rannsóknin var hluti af norræna öndvegissetrinu Justice through Education (JustEd, e.d.) sem styrkt var af NordForsk. Meginmarkmið rannsóknarinnar var að varpa ljósi á starfshætti í framhaldsskólum og pann bakgrunn og pau öfl sem móta pá. Athyglin beindist einkum að skipulagi og stjórnun skóla og skólastarfs, námi og kennslu, námsumhverfi og viðhorfum nemenda, kennara og stjórnenda til skólastarfsins. Gagna var aflað árin 2013-2014 í níu framhaldsskólum víða um land sem voru valdir með lagskiptu slembiúrtaki. Fyrir liggja vettvangslýsingar á 130 kennslustundum (167 klukkustundum), skráð viðtöl við stjórnendur, kennara og nemendur, alls 61 að tölu við samtals 100 manns, 111 sett ljósmynda úr mannlausum kennslurýmum og 90 náms- eða kennsluáætlanir, auk opinberra gagna sem safnað var. Í pessu sérriti eru birtar tíu greinar sem byggjast á fyrrnefndum gögnum. Auk peirra eru prjár greinar eftir pátttakendur í rannsóknarhópnum sem byggjast á öđrum gögnum, ein peirra á rætur í rannsókninni Skilvirkni framhaldsskóla, en tvær eru hluti af rannsókninni Framhaldsskólaval í Reykjavík og Helsinki. Rannsóknarhópurinn væntir pess að niðurstöður verði nýttar við mótun og skipulag próunarstarfs í framhaldsskólum, við stefnumótun og próun skólakerfisins í heild og að pær gagnist við bæði grunn- og símenntun kennara. Ráðgjöf um nýtingu niðurstaðna í próunarstarfi er hluti af verkefninu, ef skólar óska eftir.

Efnisord: framhaldsskóli, skipulag rannsóknar, rannsóknarlíkan, rannsóknaraðferðir.

\section{Inngangur}

Hér er lýst undirbúningi, meginmarkmiði, framkvæmd og gögnum rannsóknarinnar Starfshættir 1 framhaldsskólum, sem fram fór á árunum 2012-2018, en pátttakendur í rannsókninni standa að pessu sérriti Netlu um rannsóknir á framhaldsskólum. Um var að ræða samstarfsverkefni stórs hóps rannsakenda, bæði kennara og nemenda við Menntavísinda- og Félagsvísindasvið Háskóla Íslands, en verkefnið var vistað hjá Rannsóknastofu um próun skólastarfs á Menntavísindasviði. Hún var jafnframt hluti af norræna öndvegissetrinu Justice through Education in the Nordic Countries (JustEd, e.d.) sem starfaði á árunum 2013-2018. Rannsóknin var styrkt af Rannsóknasjóði Háskóla Íslands og NordForsk í gegnum öndvegissetrið. 
Meginmarkmið rannsóknarinnar var að varpa ljósi á starfshæetti í framhaldsskólum og pann bakgrunn og pau öfl sem móta pá. Athyglin beindist einkum að skipulagi og stjórnun skóla og skólastarfs, námi og kennslu, námsumhverfi og viðhorfum nemenda, kennara og stjórnenda til skólastarfsins. Баð var jafnframt markmið rannsóknarhópsins að niðurstöður gætu nýst við stefnumótun og próunarstarf í framhaldsskólum og íslenska skólakerfinu í heild og við próun kennaramenntunar og símenntunar kennara.

Gagna um starfshættina var aflað í níu framhaldsskólum. Fyrir liggja vettvangslýsingar á 130 kennslustundum (167 klukkustundum), 61 skráð viðtal við stjórnendur, kennara og nemendur, samtals 100 manns, 111 sett ljósmynda úr kennslurýmum (án nemenda) og 90 náms- eða kennsluáæetlanir, auk opinberra gagna af ýmsu tagi. Afraksturinn er gagnasafn sem verður að mestu leyti aðgengilegt öðrum fræðimönnum að rannsókninni lokinni. Dað getur pví orðið grunnur að langtímarannsóknum á próun starfshátta í íslenskum framhaldsskólum, jafnt sem norrænum og alpjóðlegum samanburðarrannsóknum.

Í sérritinu eru birtar prettán greinar að pessari grein meðtalinni. Tíu peirra byggjast að öllu leyti eða að hluta til á gögnum sem aflað var á vegum rannsóknarinnar Starfshættir í framhaldsskólum sem lýst er í pessari grein. Ein grein í sérritinu á rætur í rannsókninni Skilvirkni framhaldsskóla, en pað er langtímarannsókn sem staðið hefur frá árinu 2007. Tvær greinar eru hluti af rannsókninni Framhaldsskólaval í Reykjavík og Helsinki: Sjálfsmyndarsköpun á opnum markaði (sjá lýsingu á gögnum og framkvæmd viðkomandi rannsókna í pessum premur greinum).

\section{Aðdragandi og undirbúningur}

Rekja má tilurð rannsóknarinnar Starfshættir í framhaldsskólum til hugmynda sem upp komu í hópi sem stóð að rannsókninni Starfshættir í grunnskólum (sjá Gerður G. Óskarsdóttir, 2014). Áhugavert pótti að kortleggja starfshætti í framhaldsskólum líkt og gert var í grunnskólarannsókninni, ekki síst par sem fáar rannsóknir á starfsháttum framhaldsskóla lágu fyrir. Á fundi í stjórn Rannsóknastofu um próun skólastarfs í mars 2011 var pessi hugmynd síðan kynnt. Einnig var greint frá pví að hjá Rannsóknarstofu um menntakerfi á Félagsvísindasviði lægju gögn úr rannsókninni Skilvirkni framhaldsskóla, meðal annars úr spurningakönnunum meðal nemenda og kennara í framhaldsskólum, sem ekki hefði verið unnið úr nema að hluta til. Nýtt rannsóknarverkefni um framhaldsskóla gæti jafnframt nýtt pau gögn.

Með skipan stjórnar rannsóknar á starfsháttum í framhaldsskólum vorið 2011 var verkefninu síðan hrint af stað. Leitað hafði verið til Ingólfs Ásgeirs Jóhannessonar prófessors um að veita henni forystu, en Ingólfur var pá nýkominn til starfa á Menntavísindasviði. Aðrir í stjórninni voru pau Anna Kristín Sigurðardóttir prófessor, Gerður G. Óskarsdóttir menntunarfræðingur, Jón Torfi Jónasson prófessor og Kristjana Stella Blöndal dósent. Gerður var jafnframt verkefnisstjóri á undirbúnings- og gagnaöflunartímanum. Hlutverk stjórnar var að gera áætlanir um framgang rannsóknarinnar, undirbúa samkomulag aðila, gefa út kynningarefni, sækja um styrki í rannsóknarsjóði og skipuleggja nýtingu fjármagns. Jafnframt sá stjórnin um að ganga frá skráningareyðublaði og viðtalsrömmum, taka ákvarðanir um framvindu á rannsóknartímarbilinu og undirbúa sameiginlega útgáfu. Stjórnin kom reglulega saman allt tímabilið, yfirleitt með öđrum pátttakendum í rannsókninni. Ingólfur Ásgeir Jóhannesson, Elsa Eiríksdóttir og Gerður G. Óskarsdóttir tóku að sér fyrir hönd stjórnar að sitja í stýrihópi til undirbúnings pessa sérrits.

Í samkomulagi um rannsóknina eru meðal annars greinar um framkvæmd rannsóknarinnar, svo sem markmið og umgjörð, stjórn, hlutverk og skuldbindingu aðila, söfnun og úrvinnslu gagna, kynningu niðurstaðna, trúnað og loks verk- og tímaáætlun. Sérstakir kaflar eru auk pess um fjármögnun og birtingar, höfundarrétt og varðveislu gagnasafnsins. Samkomulagið var upphaflega undirritað af sjö núverandi og fyrrverandi háskólakennurum, fjórum doktorsnemum og premur meistaranemum; meirihluti hópsins með reynslu af störfum í framhaldsskólum. Síðan bættust fleiri pátttakendur við. 
Aðstandendum rannsóknarinnar var boðið að taka pátt í styrkumsókn til NordForsk, rannsóknasjóds á vegum Norrænu ráðherranefndarinnar, ásamt hópi annarra norrænna fræðimanna, pegar undirbúningur rannsóknarinnar stóð yfir, eða árið 2012, til að rannsaka réttlæti með menntun á Norðurlöndum (Justice Through Education in the Nordic Countries, skammstafað JustEd). Umsóknin fékk styrk til fimm ára, 2013-2018, sem norrænt öndvegissetur í menntarannsóknum (e. Center of Excellence) með höfuðaðsetur við Helsinkiháskóla. Setrið er hluti af menntaáæetluninni Education for Tomorrow á vegum NordForsk (Education for tomorrow, e.d.). Meginmarkmið JustEd var að kanna stöðu réttlætis og hugmynda um pað á Norðurlöndum á dögum hnattvæðingar 21. aldar. Setrið vann út frá einni víðtækri rannsóknarspurningu: Hvernig eiga kerfið, menningin og fólkið sem vinnur að menntamálum pátt í pví að stuðla að eða draga úr réttlæti við vaxandi albjóðavæðingu í velferðarríkjum Norðurlanda?

\section{Pátttakendur og erlendir samstarfsaðilar}

Hópur fræðimanna úr ýmsum greinum menntavísinda á Menntavísinda- og Félagsvísindasviði Háskóla Íslands stóð að rannsókninni Starfshættir í framhaldsskólum, alls rúmlega 20 manns. Frá upphafi tók hópur meistara- og doktorsnema pátt í rannsókninni sem hluta af meistara- eða doktorsverkefni sínu.

Að gagnaöflun á árunum 2013-2014 unnu alls fimmtán manns, pau Anna Kristín Sigurðardóttir prófessor, Elsa Eiríksdóttir dósent, Gerður G. Óskarsdóttir menntunarfræðingur, Hafdís Ingvarsdóttir prófessor, Ingólfur Ásgeir Jóhannesson prófessor, Jón Torfi Jónasson prófessor og Kristjana Stella Blöndal dósent. Einnig voru í hópnum doktorsnemarnir Bjarni Benedikt Björnsson, Guðrún Ragnarsdóttir, Súsanna Margrét Gestsdóttir og Valgerður S. Bjarnadóttir og hefur Guðrún lokið doktorsritgerð sinni sem byggist á gögnunum. Að auki tóku pátt meistaranemarnir Árný Helga Reynisdóttir, sem gerði forrannsókn árið 2012, Ásta Henriksen og Sigrún Harpa Magnúsdóttir, sem lokið hafa meistaraprófsverkefnum byggðum á gögnum rannsóknarinnar, og Inga Berg Gísladóttir, en hennar verkefni byggðist á gögnum úr rannsókninni á skilvirkni framhaldsskóla. Dau Guðrún Geirsdóttir dósent, Ingvar Sigurgeirsson prófessor og Hafrún Hafliðadóttir meistaranemi fengu síðar aðgang að gögnum rannsóknarinnar vegna samvinnu um greinar- og ritgerðarskrif. Auk pessa hóps tóku nokkrir rannsakendur pátt í fundum hópsins um skemmri eða lengri tíma.

Að JustEd-verkefninu stóđu rannsakendur við tólf háskóla á Norðurlöndunum fimm, en auk pess tóku formlegan pátt í samstarfinu ađilar frá premur háskólum annars stađar í Evrópu og í Ástralíu, samtals um 130 vísindamenn og doktorsnemar. Rannsóknarhópurinn um starfshætti í framhaldsskólum myndaði eitt af sjö teymum rannsóknarinnar. Samstarfið við JustEd-hópinn fólst meðal annars í samvinnu um einstök verkefni undir hatti heildarrannsóknarinnar, sameiginlegum málstofum og ráđstefnum, leiðsögn fyrir doktorsnema og árlegum sumarskóla fyrir doktorsefni. Dessi fjölpjóðlega tenging víkkaði umgjörð rannsóknarinnar á margan hátt, meðal annars með aukinni áherslu á að kanna möguleika framhaldsskólanemenda til að hafa áhrif á nám sitt, auk pess sem tækifæri gáfust til samvinnu við aðra pátttakendur um samanburðarathuganir.

\section{Markmið, rannsóknarspurningar og umgjörð}

Meginmarkmið rannsóknarinnar var að varpa ljósi á starfshætti í framhaldsskólum og pann bakgrunn og pau öfl sem móta pá. Athyglin beindist einkum að skipulagi og stjórnun skóla og skólastarfs, námi og kennslu, námsumhverfi og viðhorfum nemenda, kennara og stjórnenda til skólastarfsins. Réttlæti með menntun var að vissu marki rauður práđur í gegnum rannsóknina.

Við upphaf rannsóknarinnar voru settar fram prjár meginrannsóknarspurningar fyrir rannsóknina í heild. Pær voru: 
a) Hvernig eru starfshæettir í íslenskum framhaldsskólum og hvað gefa peir til kynna um próun skólanna með hliðsjón af skipulagi, námsumhverfi, kennsluháttum og námskrám?

b) Hver eru viðhorf nemenda, kennara og stjórnenda til starfshátta og próunar skólanna?

c) Hvernig tekst skólum að stuðla að skuldbindingu nemenda, hlúa að frumkvæði peirra, stuðla að réttlæti með lýðræðislegum vinnubrögðum og tryggja námsárangur og framfarir svo peir nái markmiðum sínum?

d)

Rannsóknarlíkan var sótt í smiðju rannsóknarinnar á starfsháttum í grunnskólum. Бað samanstendur af fimm samtengdum stoðum sem mynda umgjörð um rannsóknina. Sett voru fram markmið og rannsóknarspurningar fyrir hverja stoð um sig. Stoðirnar og meginpættir peirra voru:

Skipulagsstoð:Ytri og innri umgjörð skólastarfsins; skipulag og próun menntakerfis og framhaldsskóla.

Viðhorfastoð:Viðhorf til náms og kennslu og breytingar par á.

Námsumhverfisstoð: Námsumhverfi í kennslurýmum, búnaður og viðhorf kennara og nemenda til umhverfisins.

Kennarastoð: Nám og kennsla; kennsluhættir og námsaðferðir í bóklegu og verklegu námi.

Nemendastoð: Áhrif og frumkvæði nemenda og skuldbinding peirra til námsins.

Einn rannsakandi var ábyrgur fyrir hverri stoð. Gagnaöflun var skipulögð sameiginlega fyrir allar stoðirnar. Efni frá peim öllum er tekið fyrir í greinum sem birtar eru hér í sérritinu.

\section{Dátttökuskólar}

Dátttökuskólar voru níu talsins, valdir sem lagskipt slembiúrtak. Alls voru 34 framhaldsskólar nafngreindir á vefsíðu menntamálaráðuneytisins pegar úrtak skólanna var undirbúið vorið 2012. Ákveðið var að draga úrtakið úr hópi 31 skóla. Premur mjög fámennum skólum á framhaldsskólastigi sem buðu upp á stuttar sérhæfðar námsbrautir var sleppt.

Áður en val í úrtak fór fram var skólunum skipt í fimm flokka eftir gerð skóla og jafnframt í prjá flokka eftir staðsetningu á landinu. Gerðir skóla voru: „hefðbundnir“ bóknámsskólar (7), stórir og meðalstórir bók- og starfsnámsskólar (fjölbrautaskólar) (13), litlir skólar (á landsbyggðinni) (4), starfsnámsskólar (iðnskólar, verknámsskólar) (2) og loks nýir eða mikið breyttir skólar (5). Með síðasttalda flokknum er annars vegar átt við skóla sem stofnaðir voru á síðustu tveimur áratugum og höfðu frá byrjun pað markmið að breyta kennsluháttum frá pví sem almennt var á peim tíma, og hins vegar eldri skóla í miklu breytingaferli. Skólarnir voru síðan greindir í prjá flokka eftir staðsetningu á landinu: Reykjavík (9), nágrenni Reykjavíkur og Suðvesturland (9) og aðrir landshlutar (13). Í lýsingu á úrtaki er aðeins gerður greinarmunur á staðsetningu á höfuðborgarsvæðinu og öðrum landshlutum. Ekki er pessum flokkum lýst nánar eða greint frá pví hvaða skólar voru í hverjum peirra til pess að halda nafnleynd.

Dregin voru út nöfn níu skóla í lagskipta slembiúrtakið á fundi stjórnar. Pað var gert pannig að nöfn framhaldsskóla samkvæmt fyrrnefndri flokkun voru sett upp í töflu með 15 reitum, gerð skóla lóðrétt og staðsetning lárétt. Fjöldi skóla sem hafnaði í hverjum reit var frá sex niður í engan 1 fimm af reitunum. Skólunum voru gefin númer sem vísuðu til spila í stokki. Miðað var við að í úrtakinu yrði aðeins einn skóli úr hverjum reit. Ef spil kom upp sem táknaði skóla úr sama reit og áður hafði verið dregið úr var dregið aftur og enn aftur par til komnir voru níu skólar og engir tveir í sama reit. Samkvæmt flokkun eftir gerð skóla höfnuðu í úrtakinu tveir 
„hefðbundnir“ bóknámsskólar (af sjö, 29\%), fjórir stórir og meðalstórir bók- og verknámsskólar eða starfsnámsskólar (af 15, 27\%), einn lítill skóli á landsbyggðinni (af fjórum, 25\%) og tveir nýir eða mikið breyttir skólar (af fimm, 40\%). Pannig varð dreifing nokkuð jöfn á milli bóknámsskóla annars vegar og verknámsskóla hins vegar. Samkvæmt flokkun eftir staðsetningu skólanna voru fimm skólar í úrtakinu á höfuðborgarsvæðinu (af 14, 36\%; staðsettir innan svæðisins frá Hvalfirði аð Straumsvík) og fjórir í öðrum landshlutum (af 17, 24\%). Skólunum voru gefin bókstafaheiti af handahófi (til að hindra að skólar pekkist er ekki samræmi í pessum bókstafaheitum milli greina í sérritinu).

Í pessu úrtaki níu framhaldsskóla af 31 voru pví 29\% framhaldsskóla í landinu sem á pessum tíma buðu priggja til fjögurra ára nám. Fjöldi nemenda í framhaldsskólum landsins pegar rannsóknin var undirbúin veturinn 2011-2012 var um 29.400, en í skólunum níu voru alls um 9.800 nemendur eða 33\% af heildarfjöldanum (Hagstofa Íslands, e.d., tölur frá árinu 2011). Nemendafjöldi í einstökum skólum var frá um 100-200 upp í að vera um 2.000. Úrtakið endurspeglar nokkuð vel gerðir skóla, stærð peirra og staðsetningu á landinu.

\section{Forathugun og leyfi}

Forathugun var gerð í fjölmennum framhaldsskóla í Reykjavík með bóklegt og verklegt nám. Dar var undirbúningsferli heimsókna í skóla forprófað, svo og fyrirkomulag vettvangsathugana og spurningarammar viðtala. Skráningareyðublað fyrir vettvangsathuganir og viðtalsrammar voru endurskoðaðir og lagfærðir í kjölfarið.

Haft var samband við skólameistara framhaldsskólanna níu um pátttöku í rannsókninni og leyfi til gagnaöflunar og tóku allir málaleitaninni vel. Yfirleitt voru tilnefndir sérstakir tengiliðir í skólunum, einn eða tveir, sem voru rannsóknarhópnum til aðstoðar. Haldnir voru fundir með peim og heimsókn athugenda undirbúin einum eða tveimur kennsludögum fyrir komu rannsóknarhópsins.

Rannsóknin var ekki tilkynningarskyld til Persónuverndar par sem ekki var um að ræða söfnun persónugreinanlegra upplýsinga.

\section{Úrtök kennslustunda og viðmælenda}

Í hverjum skólanna níu var óskað eftir að gera vettvangsathuganir, taka ljósmyndir af kennslurýmum, eiga viðtöl við stjórnendur, kennara og nemendur og fá í hendur náms- eða kennsluáætlanir.

Við undirbúning vettvangsathugana var óskað eftir að fylgja stundaskrá nemanda af hverju námsári í áfangakerfisskólum en stundaskrá bekkja úr hverjum árgangi í bekkjakerfisskólum (sjá töflu 1). Dregin voru af handahófi nöfn bekkja eða nemenda til að fylgja eftir yfir skóladaginn (nöfn nemendanna komu hvergi fram). Reynt var að dreifa vettvangsathugunum á mismunandi námsbrautir (sjá töflu 1) og námsgreinar (sjá töflu 2). Í sumum tilfellum var beitt hentivali við val á námsbrautum nemenda til að tryggja sem mesta fjölbreytni, einkum hvað varðaði starfsnámsbrautir.

Farið var fram á að eiga að jafnaði viðtal við tvo stjórnendur í hverjum skóla, tvo til prjá kennara og tvo nemendahópa (sjá töflu 3). Óskað var eftir að tala við skólameistara og einn eða tvo millistjórnendur (fór eftir stærð skóla). Deir voru valdir með pví að draga eitt eða tvö nöfn úr hópi millistjórnenda í skólanum, lagskipt ef um tvo var að ræða.

Kennarar voru valdir í viðtöl af handahófi úr hópi peirra sem til stóð að heimsækja vegna vettvangsathugana í kennslustund. Leitast var við að taka viðtöl við kennara úr sem flestum greinum. Dess var sérstaklega gætt að í hópnum væru iðn- og starfsnámskennarar af mismunandi 
brautum, par sem við átti, og tungumálakennarar sem kenndu mismunandi tungumál (sjá töflu 2). (Sjá hér síðar um val á viðmælendum úr hópi nemenda, sem fram fór eftir að í skóla var komið).

Tengiliðir kynntu rannsóknina innan skólanna með tölvupósti og dreifðu kynningarbæklingi um hana. Deir leituðu eftir leyfi hjá kennurum vegna vettvangsathugana og hjá fyrirhuguðum viðmælendum úr hópi stjórnenda og kennara. Jákvæð svör við peirri umleitan fengust ílangflestum tilfellum. Skólastjórnendur gáfu leyfi til myndatöku í kennslustofum vegna rannsóknar á námsumhverfi. Í sumum tilfellum sáu tengiliðir um að útvega rannsóknarhópnum náms- eða kennsluáæetlanir. Rannsakendur fengu fyrir fram í hendur yfirlit yfir vettvangsathuganir og viðtöl í hverjum skóla par sem fram komu allar nauðsynlegar upplýsingar um gagnaöflunina.

\section{Framkvæmd gagnaöflunar}

Megingagnaöflunin stóð yfir frá október 2013 til nóvember 2014. Hún var skipulögð á reglubundnum fundum stjórnar verkefnisins. Hópur rannsakenda, gjarnan sjö til tíu manns, heimsótti hvern skóla og staldraði par við að jafnaði einn skóladag. Í fáeinum tilvikum fóru sumir rannsakendanna annan dag til að gera vettvangsathuganir eða taka viðtöl sem tókst ekki að ljúka á einum degi. Gerðar voru vettvangsathuganir í kennslustundum, teknar ljósmyndir í mannlausum kennslurýmum, tekin einstaklingsviðtöl við stjórnendur og kennara og hópviðtöl við nemendur, auk pess sem könnuð voru eftir atvikum skrifleg gögn frá skólum og öðrum opinberum aðilum (sjá töflur 1-3).

\section{Vettvangsathuganir í kennslustundum}

Alls liggja fyrir skráðar vettvangslýsingar á 130 kennslustundum sem voru samtals um 167 klukkustundir. Lengd stundanna var frá pví að vera 40 mínútur upp í um fjórar klukkustundir hver. Langflestar peirra, eða 82\%, stóðu í 40 til 80 mínútur.

Gerðar voru vettvangsathuganir í námshópum nemenda sem fylgt var. Í kennslustundum var leitast við að fylgjast með náms- og kennsluháttum jafnt sem viðfangsefnum, pátttöku og samskiptum nemenda. Námsumhverfið eða kennslurýmin voru jafnframt til athugunar. Dau gátu verið skólastofur, opin rými, verkstæði og útiumhverfi. Ýmist voru einn eða tveir athugendur í hverri kennslustund; einn í 73 kennslustundanna (56\%) sem fylgst var með, en tveir í 57 stundum (44\%) og skráđu pá vettvangslýsingu sameiginlega. Deir komu sér gjarnan fyrir með fartölvur sínar aftast í stofu eða til hliðar en gengu stundum á milli nemenda til frekari athugunar á vinnu peirra.

Fylgst var með nemendum á mismundi námsárum, eða 25 kennslustundum nemenda sem skráđir voru á fyrsta ári, 37 á öđru ári, 45 á priðja ári og 23 á fjórða ári (sjá töflu 1). Nánar tiltekið var fylgt að minnsta kosti einum nemanda eða bekk á hverju námsári í öllum skólunum og bætt við einum eða tveimur nemendum í stærri skólum og skólum með starfsnámsbrautir. Í skólum með skipulegt priggja ára nám til stúdentsprófs var fylgt tveimur til premur nemendum á priðja ári. Tekið skal fram að í viðkomandi kennslustundum gátu verið nemendur af mismunandi námsárum og pótt fylgt hafi verið nemanda á öðru ári, sem dæmi, voru sumir áfangar fyrsta árs áfangar. Sama gildir um nemendur á priðja ári. 
Tafla 1. Yfirlit yfir fjölda vettvangsathugana í kennslustundum eftir árgöngum nemenda og námsbrautum bekkja eða nemenda sem fylgt var.

\begin{tabular}{|c|c|c|c|c|c|}
\hline $\begin{array}{l}\text { Námsár } \\
\text { nemanda eða } \\
\text { bekkjar sem } \\
\text { fylgt var }\end{array}$ & $\begin{array}{l}\text { Fjöldi } \\
\text { nemenda/ } \\
\text { bekkja sem } \\
\text { fylgt var }\end{array}$ & $\begin{array}{l}\text { Fjöldi } \\
\text { kennslu- } \\
\text { stunda/ } \\
\text { vettvangs } \\
\text { lýsinga }\end{array}$ & $\begin{array}{l}\text { Námsbrautir (gróf flokkun): bekkir eða } \\
\text { nemendur sem fylgt var (samnemendur } \\
\text { gátu verið af ólíkum brautum, par } \\
\text { með töldum almennum brautum og } \\
\text { framhaldsskólabrautum, en nemendur af } \\
\text { peim brautum voru sjaldan dregnir út) }\end{array}$ & $\begin{array}{l}\text { Fjöldi bekkja/ } \\
\text { nemenda sem } \\
\text { fylgt var }\end{array}$ & Hlutfall \\
\hline 1. ár & 10 & 25 & Bóknámsbrautir & 31 & $69 \%$ \\
\hline 2. ár & 10 & 37 & Starfs- og listnámsbrautir & 14 & $31 \%$ \\
\hline 3. ár & 14 & 45 & & & \\
\hline 4. ár & 11 & 23 & & & \\
\hline Alls & 45 & 130 & & 45 & $100 \%$ \\
\hline
\end{tabular}

Fylgt var eftir fjórum til sex nemendum (íáfangakerfi) eða bekkjum (í bekkjakerfi) á mismunandi brautum yfir daginn sem gagnaöflun fór fram í viðkomandi skóla, alls 45 nemendum/bekkjum og var 31 nemandi á bóknámsbrautum og fjórtán á verk- og listnámsbrautum (sjá töflu 1). Í sex tilfellum féllu vettvangsathuganir niður. Ástæður pess voru meðal annars pær að stundaskrá nemenda breyttist vegna vettvangsferðar, próf var á dagskrá eða kennari var veikur, og í tveimur tilvikum færðust kennarar undan pví að fylgst yrði með kennslunni.

Námsgreinar í kennslustundunum sem fylgst var með voru flokkaðar í ellefu námsgreinaflokka og voru frá tveimur greinum upp í 20 í hverjum flokki (sjá töflu 2). Detta gátu verið kjarnagreinar, greinar í brautarkjarna eða valgreinar. Sumar námsgreinar liggja á mörkum flokka og höfundar fræðigreina sem vinna úr gögnunum flokka pær pví stundum á mismunandi hátt, til dæmis voru áfangar um ljósmyndun flokkaðir hér undir sjónlistir og hönnun en í annarri grein eru peir flokkaðir sem iðnnám.

Tafla 2. Yfirlit yfir vettvangsathuganir og kennaraviðtöl, flokkuð eftir námsgreinaflokkum.

\begin{tabular}{lcc}
\hline Námsgreinaflokkur & $\begin{array}{c}\text { Vettvangs- } \\
\text { lýsingar }\end{array}$ & $\begin{array}{c}\text { Kennara- } \\
\text { viðtöl }\end{array}$ \\
\hline Erlend tungumál (alls fimm tungumál) & 20 & 7 \\
Félagsvísindagreinar (félags-, uppeldis- og viðskiptafræði og lífsleikni) & 18 & 2 \\
Hugvísindagreinar (saga og heimspeki, p.m.t. siðfræði) & 11 & \\
Iðn- og starfsnámsgreinar, bóklegar og verklegar (af sex námsbrautum; & & \\
ekki sundurliðaðar til að koma í veg fyrir að skólar í úrtakinu pekkist & & 6 \\
út frá peim) & 18 & 1 \\
Íslenska & 12 & \\
Ípróttir (bæði bóklegar og hreyfing) & 5 & 2 \\
Náttúruvísindagreinar (eðlis-, efna-, líf-, jarð-, landa- og & & \\
umhverfisfræði) & 18 & 5 \\
Sjónlistir og hönnun & 6 & \\
Stærðfræði & 14 & \\
Tölvufræði & 2 & \\
Dverfaglegt nám & 6 & \\
\hline Alls & 130 &
\end{tabular}

Skráningareyðublað var hannað fyrir vettvangsathuganir og lýsingar á kennslurýmum. Dar voru tilgreindar bakgrunnsupplýsingar, svo sem dagsetning, tími dags, tákn skóla, kyn kennara, námsgrein og heiti áfanga. Einnig var skrád námsár nemanda eða bekkjar sem fylgt var, fjöldi nemenda sem mættur var í kennslustundina, skipt eftir kynjum, og ef kostur var fjöldi nemenda 
sem skráður var í viðkomandi áfanga. Skráningareyðublaðið skiptist síðan í tvo meginpætti. Fyrst var kennslurýminu lýst, par með talið skipulag og uppröðun húsgagna, efni á veggjum og búnaður. Pá kom lýsing á kennslustundinni í samfelldu máli með tímasetningum (tíminn yfirleitt skráður á 5-10 mínútna fresti), skipt í upphaf, framvindu og lok. Í framvindulýsingu voru tveir dálkar, annar fyrir pað sem kennari gerði og hinn fyrir framlag nemenda. Námsefni viðkomandi áfanga var skráð sérstaklega. Lýsingunni var fylgt eftir með stuttri samantekt athuganda á kennslustundinni, svo sem um megininntak, helstu aðferðir, hlut kennara og virkni nemenda, auk hugleiðinga um kennslustundina.

Fyrir liggja 111 sett ljósmynda sem teknar voru í kennslurýmum í framhaldsskólunum níu, frá fjórum til sex eða fleiri í hverju rými, til að fá heildarmynd af skipulagi pess og búnaði. Myndirnar voru yfirleitt teknar eftir að nemendur voru farnir úr viðkomandi stofu. Áhersla var lögð á að sýna uppröðun húsgagna, tækjabúnað og efni á veggjum. Í sumum tilvikum voru myndir ekki teknar, til dæmis vegna pess að nemendur fóru ekki úr kennslustofunni eða að stofan hafði verið mynduð áður.

Upplýsingar úr hverri vettvangsathugun voru skráđar í rafrænan gagnagrunn að henni lokinni til að auðvelda úrvinnslu. Skráningin skiptist í sex meginpætti. Fyrst voru skráðar sömu bakgrunnsupplýsingar og á skráningareyðublaðinu. Lýsing á skólastofu var sett inn í rafræna grunninn. Henni fylgdu upplýsingar um uppröðun nemenda í stofunni, notkun kennslutækja og tölvunotkun sérstaklega. Pví næst kom skráning um heimanám, kennsluaðferðir sem beitt var og upplýsingar um hlut nemenda, svo sem val peirra um viðfangsefni og möguleika á frumkvæði. Loks var samantektin af vettvangseyðublaðinu sett inn í grunninn. Að gagnaöflunartímabilinu liðnu var gagnagrunnurinn yfirfarinn og villur leiðréttar.

\section{Viðtöl við stjórnendur, kennara og nemendur}

Viðtöl voru tekin við nemendur, kennara og stjórnendur í framhaldsskólunum níu til að afla upplýsinga um reynslu peirra, viðhorf og sýn á skólastarfið og skipulag pess, alls 61 talsins (sjá töflu 3 og 2) með alls 100 pátttakendum. Pau fóru yfirleitt fram sömu daga og vettvangsathuganirnar og stóðu í allt að eina klukkustund hvert. Viðtölin voru hálfopin og stuðst var við viðtalsramma sem voru mismunandi eftir pví hver pessara priggja hópa átti í hlut. Áherslur í viðtalsrömmum endurspegluðu markmið stoðanna fimm. Rannsakendur hittu viðmælendur sína í viðtals- og fundarherbergjum, á skrifstofum starfsmanna eða í kennslustofum. Öll viðtölin voru hljóðrituð og afrituð orðrétt.

Tafla 3. Yfirlit yfir skráð viðtöl - viðmælendur og fjöldi peirra.

\begin{tabular}{lc}
\hline Viðmælendur & Fjöldi viðtala \\
\hline $\begin{array}{l}\text { Skólameistarar, einstaklingsviðtöl um sýn peirra, skipulag og stjórnun } \\
\text { skólanna }\end{array}$ & 9 \\
$\begin{array}{l}\text { Millistjórnendur, einstaklingsviðtöl um sýn peirra, skipulag og stjórnun } \\
\text { skólanna }\end{array}$ & 12 \\
Kennarar, einstaklingsviðtöl um kennsluhætti og viðfangsefni nemenda & 23 \\
Nemendur, hópviðtöl um námsumhverfi, nám og kennslu & 17 \\
\hline Alls & 61
\end{tabular}

Stjórnendaviðtöl: Tekin voru einstaklingsviðtöl við skólameistara framhaldsskólanna níu. Einnig var rætt við millistjórnendur í hverjum skóla, alls tólf, tvo í stærri skólum en einn í peim minni (sjá töflu 3). Allir stjórnendur sampykktu pátttöku (sjá kafla um úrtök viðmælenda). Tveir rannsakendur voru í flestum viðtalanna. Efni peirra snerist meðal annars um sýn viðmælenda á skólastarfið, nemendahópinn í skólanum, störf peirra með kennurum og eigið forystuhlutverk, námsmat og samstarf innan sem utan skólans. Einnig var spurt um starfspróun kennara, 
próunarstarf í skólanum og nýtingu niðurstaðna úr rannsóknum í peim efnum. Loks var fjallað um starfsumhverfi skólans og próun skólakerfisins í nútíð og framtíð.

Kennaraviðtöl: Rannsakendur tóku einstaklingsviðtöl við tvo til prjá kennaraí hverjum skóla. Fyrir liggja alls 23 afrituð viðtöl (sjá töflur 2 og 3; sjá kafla um úrtök viðmælenda). Fjórir rannsakendur skiptu með sér ábyrgð á hverju kennaraviðtali, en í fimm viðtölum af 23 voru athugendur tveir. Í tveimur tilvikum sampykkti kennari ekki pátttöku og var pá annar valinn, eitt viðtal féll niður af óviðráðanlegum ástæðum og í einu tilviki eyðilagðist upptaka. Meginefni viðtala við kennara var kennsluhættir og sýn á nám og kennslu. Spurt var um kennsluaðferðir og próun peirra, svo og aðstæður og nýtingu tölva og samfélagsmiðla, meðal annars með vísan í kennslustundina sem fylgst var með. Pá var spurt um námskrá, val á námsefni og viðfangsefnum nemenda, bæði hópa og einstaklinga, auk heimanáms. Sérstaklega var spurt um möguleika nemenda á að velja sér viðfangsefni eða hafa áhrif á námið og framgang pess. Jafnframt var vikið að samstarfi kennara í skólanum, námsmati og próunarstarfi almennt. Loks var spurt um kennsluferil viðmælanda og undirbúning undir kennarastarfið. Kennarar í iðn- og starfsnámsgreinum voru jafnframt spurðir um samspil bóklegs og verklegs náms og tengingu skólanáms og vinnustaðanáms.

Nemendaviðtöl: Hópviðtöl fóru fram við tvo nemendahópa í hverjum framhaldsskólanna níu nema einum, par sem var aðeins eitt viðtal, samtals sautján hópa. Leitað var eftir sjálfboðaliðum til pátttöku úr hópi átján ára nemenda og par með sjálfráđa. Valdar voru af handahófi kennslustundir sem rannsakendur heimsóttu par sem meirihluti nemenda var á priðja eða fjórða ári og í lok kennslustundarinnar var óskað eftir sjálfboðaliðum í viðtölin. Nemendur tóku í öllum tilfellum vel í pá málaleitan. Í hverjum hópi voru tveir til fimm nemendur, að meðaltali prír, alls 56 eða 30 stúlkur og 26 piltar. Fjórir rannsakendur skiptu með sér ábyrgð á viðtölunum við nemendur. Einn rannsakandi tók viðtöl við tíu nemendahópa, en tveir við sjö peirra.

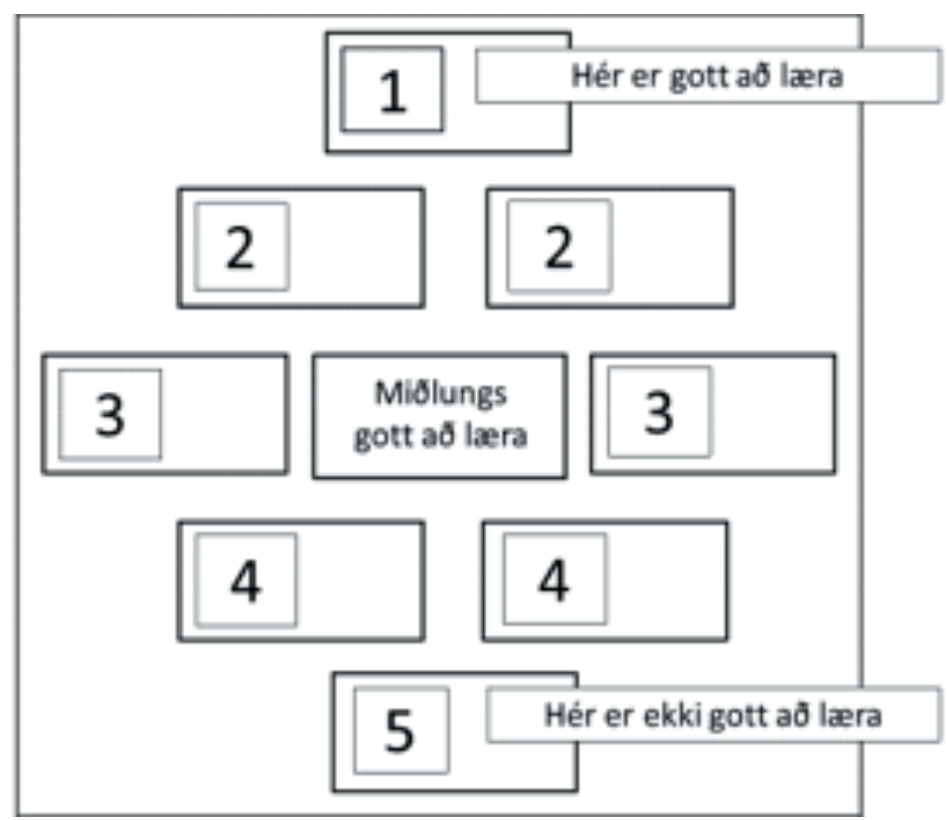

Mynd 1. Tígulforgangsröðun (e. diamond ranking activity) (sjá nánar í Clark, Laing, Tiplady og Woolner, 2013 og Clark, 2012).

Nemendaviðtölin skiptust í prjá meginpætti. Fyrsti hlutinn fólst í umræðum um námsumhverfið. Til að auðvelda umræðuna var beitt svokallaðri tígulforgangsröðun (e. diamond ranking activity; Clark, 2012) (sjá mynd 1). Hún fólst í pví að sýna nemendum tólf myndir af mismunandi námsumhverfi, svo sem í hefðbundinni kennslustofu par sem allir sitja og hlusta á kennarann, á 
bókasafni við lestur eða við hópborð par sem nemendur vinna saman. Nemendum var síðan ætlað að raða myndunum í forgangsröð á spjald (stærð A3) með níu reitum sem raðað var í tígulform $(1+2+3+2+1$ mynd; sbr. mynd 1). Efst skyldi raða myndum af aðstæðum sem peim pótti best að læra við og neðst peim sem nemendum líkaði síst við. Nemendur ákváðu hvaða premur myndum skyldi hafnað af peim tólf sem fyrir lágu. Rannsakandi tók ljósmynd af niðurstöðunni. Dví næst var rætt um nám og kennslu, meðal annars út frá fyrrnefndum myndum, og nemendur spurðir um algengustu kennsluaðferðir, nýtingu tölvutækninnar, námsmat og heimanám. Loks voru nemendur spurðir um áhrif peirra á námið og framvindu pess, möguleika á vali um viðfangsefni, tækifæri til frumkvæðis, skuldbindingu peirra gagnvart náminu, pátttöku í ákvörðunum um skólastarfið í heild og starfsanda. Iðn- og starfsnámsnemar voru sérstaklega spurðir um tengsl bóklegs og verklegs hluta námsins og vinnustaðanámið.

\section{Önnur gögn frá framhaldsskólunum}

Auk peirra rannsóknargagna sem lýst er hér framar voru einnig skoðuð lög og reglugerðir um framhaldsskóla, par með talin Aðalnámskrá framhaldsskóla, náms- eða kennsluáætlanir í áföngum par sem vettvangsathuganir fóru fram og önnur opinber gögn. Í sumum tilfellum útvegaði tengiliður áætlanirnar fyrir heimsókn rannsóknarhópsins, í öðrum höfðu kennarar pær tiltækar í vettvangsheimsókn og í enn öđrum lágu pær fyrir á heimasíðu skólans. Í gagnasafni rannsóknarinnar eru um 90 áætlanir. Skýrslur um próunarverkefni og matsskýrslur í einstökum pátttökuskólum og einstök verkefni nemenda í kennslustundum par sem vettvangsathuganir fóru fram voru einnig til skoðunar.

\section{Greining og túlkun - fyrirvarar um réttmæti og áreiðanleika}

Efni í fyrirliggjandi vettvangslýsingum var greint út frá ýmsum sjónarhornum. Rannsakendur lögðu áherslu á ólíka pætti, svo sem námsumhverfi, kennsluhætti, viðfangsefni nemenda, áhrif peirra og frumkvæði. Unnið var úr viðtölum við stjórnendur, kennara og nemendur frá ýmsum sjónarhólum. Viðtölin voru greind eftir pemum og áherslupáttum einstakra stoða eða pvert á stoðir rannsóknarinnar. (Sjá nánar í einstökum greinum í pessu sérriti, en einnig í prófritgerðum, tímaritsgreinum og bókarköflum sem hafa birst og byggjast á gögnum úr rannsókninni.)

Túlkun niðurstaðna um starfshætti í íslenskum framhaldsskólum var unnin í ljósi markmiða, lykiláherslna og rannsóknarspurninga fyrir rannsóknina í heild. Tekið var mið af peim stoðum sem lágu rannsókninni til grundvallar, svo og fræðilegri innlendri og alpjóðlegri umræðu. Túlkunin tók einnig mið af stefnumörkun um framhaldsskóla á Íslandi sem meðal annars birtist í lögum, reglugerðum og aðalnámskrá, stundum með tilvísun í fjölpjóðleg stefnuskjöl.

Fjölbreyttum gögnum var safnað í níu nokkuð ólíkum framhaldsskólum víðs vegar um landið, bæði í bóklegu og verklegu námi. Miðað við fjölda skóla og nemenda í pessum skólum er úrtakið nokkuð stórt (29\% framhaldsskóla og 33\% framhaldsskólanemenda) og pess vegna tilefni til að ætla að sú mynd sem fæst spegli starf framhaldsskólanna í landinu almennt nokkuð vel. Dar að auki reyndist vera talsverð samsvörun í starfsháttum milli skóla af sömu eða svipaðri gerð. Dess vegna er ekki ástæða til að ætla að stærra úrtak hefði gefið ólíka mynd. Að pví sögðu telur rannsóknarhópurinn að niðurstöður gefi góða mynd af stjórnun, skipulagi, námsumhverfi, kennsluaðferðum og viðhorfum stjórnenda, kennara og nemenda í íslenskum framhaldsskólum og auki til muna pekkingu og skilning á framhaldsskólastarfi í landinu.

Til að auka réttmæti gagnanna var horft á starfshættina frá ólíkum sjónarhornum, pað er með vettvangsathugunum í 130 kennslustundum, 61 viðtali við prjá mismunandi hópa, stjórnendur, kennara og nemendur, ljósmyndum af námsumhverfi og könnun á fyrirliggjandi gögnum frá skólum og öðrum opinberum aðilum. 
Dótt fyrir liggi lýsingar á fjölda kennslustunda í ólíkum námsgreinum verður að hafa í huga að hér er aðeins um að ræða örlítið brot af peirri kennslu sem fram fer í framhaldsskólum landsins ár hvert. Rannsakendur dvöldu aðeins einn dag í hverjum skóla og pví er ekki tekið mið af samhengi við pað sem kom á undan og pað sem var gert síðar í skólastarfinu. Hafa ber í huga að pótt margs konar pættir hafi verið skráđir í hverri kennslustund er ekki ólíklegt að ýmislegt hafi farið fram hjá skrásetjurum og pað sem auðvelt var að skrá hafi fremur ratað í vettvangslýsingar. Til að vinna gegn pví og styrkja um leið áreiðanleika niðurstaðna fóru tveir athugendur saman í 44\% kennslustundanna og skráðu sameiginlega lýsingu (báđir skráðu lýsingu í kennslustund og sameinuðu pær síðan). Detta jók samræmi milli vettvangslýsinga.

Til að stuðla að samræmi í viðtölum var stuðst við viðtalsramma sem fylgt var að miklu leyti pótt stundum breyttist röð efnisatriða. Dó ber að hafa í huga pau áhrif sem rannsakandi getur hugsanlega haft á viðmælanda, svo sem að hann svari pví sem hann telur að spyrjandi vilji heyra. Ekki er heldur ólíklegt að nemendur í hópviðtölum hafi haft áhrif á skoðanir hver annars og minnt skal á að pátttakendur komu sem sjálfboðaliðar í viðtölin og pví er sá viðtalshópur ekki pversnið af nemendum í framhaldsskólum. Gera má ráð fyrir að peir sem buðu sig fram hafi fremur verið nemendur sem höfðu kjark og vilja til að ræða hugmyndir sínar og skoðanir. Einnig skal bent á að öll viðtölin tóku á mörgum páttum og pví gafst ekki tækifæri til að kafa djúpt í efnið.

Hópur fólks kom að gagnaöfluninni og pað gefur henni ákveðið gildi. En pað á við um pessa rannsókn eins og aðrar að ætla má að viðhorf, pekking og reynsla skrásetjara vettvangslýsinga og spyrjenda í viðtölum hafi haft áhrif á pað sem skráð var og spurt um og ekki síður á túlkun niðurstaðna. Í pessu sambandi ber pó að geta pess að rannsakendurnir ræddu saman bæði á fundum og óformlega eftir hverja skólaheimsókn og samræmdu pannig enn frekar aðferðir sínar og túlkanir. Аð auki hefur rannsóknarhópurinn lesið og rætt handrit sem pátttakendur hafa skrifað á umræðufundum, miðlað hugmyndum og veitt margvíslega endurgjöf.

\section{Gildi rannsóknarinnar}

Lítið hefur verið um rannsóknir á íslenskum framhaldsskólum og starfsháttum peirra. Fyrirliggjandi rannsóknir fjalla um einstök viðfangsefni og gefa pví ekki heildarmynd af starfi skólastigsins. Dessi rannsókn er pví mikilvæg sem fyrsta heildarrannsókn á framhaldsskólastiginu á Íslandi par sem gefið er yfirlit yfir stjórnun, skipulag og húsnæði skólanna jafnt sem kennslu og nám nemenda, auk pess sem viðhorfum nemenda, kennara og stjórnenda eru gerð skil.

Gagnasafnið verður að mestu leyti aðgengilegt öðrum fræðimönnum að rannsókninni lokinni til frekari rannsókna á framhaldsskólum og sem grunnur að íslenskum og alljóðlegum samanburðarog langtímarannsóknum á próun starfshátta í framhaldsskólum. Safnið býr yfir fjölmörgum tækifærum til enn frekari úrvinnslu.

Rannsóknarhópurinn vill stuðla að pví að niðurstöður verði nýttar við skipulag próunarstarfs í framhaldsskólum og próun skólakerfisins í heild, svo og í grunn- og símenntun kennara. Hópurinn hefur haldið fjölmörg erindi um niðurstöður sínar í einstökum framhaldsskólum og á ráđstefnum um rannsóknir og próunarstarf á framhaldsskólastiginu. Ráðgjöf um nýtingu niðurstaðna í próunarstarfi er jafnframt hluti af verkefninu, ef skólar óska eftir. Áhugasamir geta snúið sér til meðlima úr stjórn rannsóknarinnar (sjá hér framar). 
Upper Secondary School Practices in Iceland: Research project 2012-2018: Method

This research project Upper secondary school practices in Iceland was carried out in 2012-2018. It was a cooperative undertaking by over 20 researchers, including teachers and graduate students at the Schools of Education and Social Sciences at the University of Iceland, and located in the Centre for Research in Educational Development, School of Education. The project was associated with the Nordic Centre of Excellence: Justice through Education in the Nordic Countries (JustEd, n.d.), 2012-2018, supported by NordForsk (an organisation providing funding for Nordic cooperation in research). The centre focused on the question: How do systems, cultures and actors in education facilitate and constrain justice in the context of globalising Nordic welfare states? This study was carried out by one of its seven teams.

The main objectives of the research project were to provide an understanding of teaching and learning in upper secondary schools in Iceland and the moulding forces of their evolution. A special emphasis was placed on educational structures, administration, the physical learning environment, teaching strategies, views within the institution and student influence, engagement and initiative.

The research framework included five strands. The first focused on the structures of the upper secondary schools, official initiatives and the relationship between current practices and intended changes, as presented in the educational policy introduced by legislation (2008) and the curriculum (2011). The second strand was intended to throw light on teachers' views towards education, covering their beliefs on the effect of current practices on student learning, including structure, curriculum, teaching, and learning. Strand three pointed to the current physical environment in the schools, especially classrooms, focusing on features of change in school buildings, reflecting new challenges involving architecture, educational ideology and school policy. The fourth strand was directed towards exploring current classroom practices, including various teaching methods, especially in terms of the national curriculum set in 2011. Finally, the fifth strand focused on student influence, engagement and initiative in the learning process, as well as students' opportunities to influence school governance.

Data was collected during 2013 and 2014 in nine upper secondary schools located around the country, chosen as a stratified random sample out of a total of 31 . The student population numbered from around 200 up to 2,000 in each school, representing $33 \%$ of the total student population in Icelandic upper secondary schools. This paper describes the methodology in detail.

The data covers: a) Classroom observations supported by an observation frame, conducted during 130 randomly selected lessons (167 hours). Classes or individual students were followed during one school day, by one (56\%) or two researchers (44\%); b) Photos taken in each classroom (after students had left the room), a total of 111 sets, focusing on furniture arrangement, educational equipment and material displayed on walls; c) A total of 61 recorded interviews with 100 people, supported by interview frames: firstly, with nine heads of school and twelve members of middle management; secondly, with two to three selected teachers in each school, a total of 23; thirdly, with seventeen groups of students consisting of 56 volunteers, eighteen years old or older; and d) Educational documents like lesson plans and school curricula.

The results will serve as a database for longitudinal and comparative research. It is expected that the study will support development in upper secondary schools, the school system in general, and teacher education. Consultancy on behalf of the research group, upon request, is a component of the project. 
In this special issue of Netla there are ten articles based on data from the above research project (this article included). In addition, one is rooted in a longitudinal research project, School effectiveness and students' educational progress, commencing in 2007, and two in a study on school choice at the upper secondary level in both Reykjavik and Helsinki.

Key words: upper secondary schools, research plan, research framework, research methods.

\section{Um höfundinn}

Gerður G. Óskarsdóttir (gerdurgo@simnet.is) lauk doktorsprófi í menntunarfræði frá Kaliforníuháskóla í Berkeley 1994, meistaraprófi í námsrádgjöf frá Bostonháskóla 1981, BA-prófi frá Háskóla Íslands 1969 og kennaraprófi frá Kennaraskóla Íslands 1964. Gerður hefur starfað sem kennari og stjórnandi á grunn-, framhalds- og háskólastigi, ráðunautur menntamálaráðherra og yfirmaður leik- og grunnskóla Reykjavíkurborgar. Rannsóknir hennar hafa einkum snúist um brotthvarf, tengsl menntunar og starfs, náms- og starfsráðgjöf, kennsluhætti og skil skólastiga.

\section{About the author}

Gerður G. Óskarsdóttir (gerdurgo@simnet.is) completed a PhD in educational administration from the University of California at Berkeley in 1994, an MEd in school counseling from Boston University in 1981, a BA from the University of Iceland in 1969, and diplomas for teaching certificates in 1971 and 1964. Gerður has served as teacher and administrator at primary, secondary and university levels, and has been a consultant to the minister of education and superintendent of schools in the Reykjavik district. Her research has focused on dropouts, school-to-work relations, school counseling, teaching and learning, and educational transitions.

\section{Heimildir}

Clark, J. (2012). Using diamond ranking as visual cues to engage young people in the research process. Qualitative Research Journal, 12(2), 222-237. doi: 10.1108/14439881211248365

Clark, J., Laing, K., Tiplady, L. og Woolner, P. (2013). Diamond ranking activity. Making connections: Theory and practice of using visual methods to aid participation in research. Newcastle: Research Centre for Learning and Teaching, Newcastle University.

Education for tomorrow. (e.d.). Sótt af http://www.nordforsk.org/en/programs/programmer/education-for-tomorrow-1/education-for-tomorrow

Gerður G. Óskarsdóttir (ritstjóri). (2014). Starfshettir í grunnskólum við upphaf 21. aldar. Reykjavík: Háskólaútgáfan.

Hagstofa Íslands. (e.d.). Talnaefni. Skólamál. Framhaldsskólar. Sótt af http://www.hagstofa.is/Hagtolur/Skolamal/Framhaldsskolar

Háskóli Íslands, Menntavísindasvið. (2013). Starfshattir í framhaldsskólum. Rannsóknarverkefni 2013-2016 [kynningarbæklingur].

JustEd [Nordic Centre of Excellence. Justice Through Education in the Nordic Countries]. (e.d.). Sótt af http://blogs.helsinki.fi/just-ed/

\section{Viðauki}

Eftirfarandi bókarkaflar, greinar og ritgerðir sem byggjast á gögnum sem safnað var í rannsókninni Starfshættir í framhaldsskólum hafa pegar birst eða eru á lokastigi: 


\section{Bókarkaflar og tímaritsgreinar}

Anna Kristín Sigurðardóttir. (2017). Student-centred classroom environments in upper secondary school: Students' ideas about good spaces for learning versus actual arrangements. Í L. Benade og M. Jackson (ritstjórar), Transforming education: Design E governance in global contexts (bls. 183-197). Singapore: Springer.

Árný Helga Reynisdóttir og Ingólfur Ásgeir Jóhannesson. (2013). Fleiri vindar blása.Viðhorf reyndra framhaldsskólakennara til breytinga í skólastarfi 1986-2012. Netla - Veftímarit um uppeldi og menntun. Sótt af http://netla.hi.is/greinar/2013/ryn/006.pdf

Elsa Eiríksdóttir og Ingólfur Ásgeir Jóhannesson. (2016). Sjónarmið stærðfræði- og verkgreinakennara í framhaldsskólum um hvaða öfl hafa áhrif á starfshætti: Námsmat og upplýsingatækni. Tímarit um uppeldi og menntun, 25(2), 197-218.

Elsa Eiríksdóttir og Roswall, P.-Å. ('́ ritrýni).VET teachers' interpretations of individualisation and teaching of skills and social order in two Nordic countries. European Educational Research Journal.

Hafdís Ingvarsdóttir. (2016). In times of changing linguistic context:The career trajectory of an EFL teacher in Iceland. Í P. Haworth og C. Craig (ritstjórar), The career trajectories of English language teachers (bls. 95-104). Oxford: Symposium Books.

Nylund, M., Rosvall, P.-Å., Elsa Eiríksdóttir, Holm, A.-S., Isopahkala-Bouret, U., Niemi A.-M. og Guðrún Ragnarsdóttir. (2018). The academic-vocational divide in three Nordic countries: Implications for social class and gender. Education Inquiry, 9(1), 97-121. doi:10.1080/20004508.2018.1424490

Valgerður S. Bjarnadóttir og Guðrún Geirsdóttir. (2018). 'You know, nothing changes'. Students' experiences in influencing pedagogic practices in various upper secondary schools in Iceland. Pedagogy, Culture E Society, 26(4), 631-646. doi:10.1080/14681366.2018.1439995

\section{Doktorsverkefni}

Guðrún Ragnarsdóttir. (2018). School leaders' perceptions of contemporary change at the upper secondary school level in Iceland. Interaction of actors and social structures facilitating or constraining change (óutgefin doktorsritgerð). Háskóli Íslands, Reykjavík.

Valgerður S. Bjarnadóttir. (e.d.).The complexities of student influence in upper secondary schools in Iceland: Pedagogic practice and subject hierarchies (doktorsritgerð á lokastigi). Háskóli Íslands, Reykjavík.

\section{Meistaraverkefni}

Árný Helga Reynisdóttir. (2013). Skóli á tímamótum? Viðhorf reyndra framhaldsskólakennara til breytinga í skólastarfinu (óútgefin meistararitgerð). Háskóli Íslands, Reykjavík.

Ásta Henriksen. (2015). Sköpun í tungumálanámi. Viðhorf tungumálakennara í framhaldsskólum til skapandi kennsluhátta (óútgefin meistararitgerð). Háskóli Íslands, Reykjavík.

Hafrún Hafliðadóttir. (e.d.). Virkni nemenda í kennslustundum í framhaldsskólum á Íslandi. Einkenni og áhrifavaldar (meistararitgerð á vinnslustigi). Háskóli Íslands, Reykjavík.

Sigrún Harpa Magnúsdóttir. (2015). Hugmyndir nemenda í framhaldsskólum um gott námsumhverfi (óútgefin meistararitgerð). Háskóli Íslands, Reykjavík.

Gerður G. Óskarsdóttir og rannsóknarhópur um starfshætti í framhaldsskólum. (2018).

Starfshættir í framhaldsskólum: Aðdragandi og framkvæmd rannsóknar 2012-2018.

Netla - veftímarit um uppeldi og menntun. Sérrit 2018 - Framhaldsskólinn í brennidepli.

Menntavísindasvið Háskóla Íslands.

Sótt af http://netla.hi.is/serrit/2018/framhaldskolinn_brennidepli/01.pdf

DOI: https://doi.org/10.24270/serritnetla.2019.1 